\title{
ANALISIS BANJIR DENGAN METODE MUSKINGUM CUNGE DAN SISTEM INFORMASI GEOGRAFIS (SIG) DI KELURAHAN BANYUANYAR, SURAKARTA
}

\author{
Muhammad Zean Raka Buana ${ }^{1}$, Rintis Hadiani ${ }^{2}$, dan Endah Sitaresmi Suryandari ${ }^{3)}$ \\ 1) Mahasiswa Fakultas Teknik, Prodi Teknik Sipil, Universitas Sebelas Maret \\ 2) Pengajar Fakultas Teknik, Prodi Teknik Sipil, Universitas Sebelas Maret \\ 3) Kepala Dinas Pekerjaan Umum Kota Surakarta \\ Jl. Ir. Sutami 36A, Surakarta 57126; Telp. 0271-634524. Email: buanaraka@hotmail.com
}

\begin{abstract}
Surakarta, Banyuanyar village that usually flooded with bad condition for several years back then. Flood happen because water runoff from Kali Pepe Hulu, the things that should do is make prevention action to create inundation mapping based on flood routing using the Muskingum Cunge method. Flood routing is based on events return period and 2 days rainfall, which will then be mapped using Geographic Information System (GIS).

The result of this research shows that maximum debit for 5 years return period is 143,748 $\mathrm{m}^{3} /$ second, that caused inundation area 122.568,098 $\mathrm{m}^{2}$. The maximum debit for 10 years return period is $196,693 \mathrm{~m}^{3} /$ second, that caused inundation area 148.995,304 $\mathrm{m}^{2}$. The maximum debit for 25 years return period is 309,434 $\mathrm{m}^{3} /$ second, that caused inundation area 206.264,739 $\mathrm{m}^{2}$. The maximum debit for 50 years return period is 483,759 $\mathrm{m}^{3} /$ second, that caused inundation area 255.356,377 $\mathrm{m}^{2}$. The maximum 2-days rainfall debit happened in the year of 2009 is $281,846 \mathrm{~m}^{3} /$ second, that cause inundation area $188.141,935 \mathrm{~m}^{2}$.
\end{abstract}

Keywords : Banyuanyar Village, Flood Routing, Muskingum Cunge Method, Geographical Information System.

\begin{abstract}
Abstrak
Surakarta, kecamatan Banjarsari, tepatnya di kelurahan Banyuanyar merupakan daerah yang tidak luput dari peristiwa banjir dengan kondisi yang cukup parah dibeberapa tahun belakangan. Banjir terjadi dikarekan limpasan air dari Kali Pepe Hulu, hal yang perlu dilakukan untuk mengatasi permasalahan tersebut salah satunya dengan penelusuran banjir dengan metode Muskingum Cunge dan juga pemetaan banjir. Menggunakan data debit periode ulang (Qt) dilakukan penelusuran banjir, selanjutnya pemetaan banjir yang diakibatkan oleh hujan 2 harian maksimal tahunan menggunakan Sistem Informasi Geografis (SIG).

Hasil dari penelitian ini menunjukkan bahwa debit banjir maksimum kala ulang 5 tahunan adalah 143,748 $\mathrm{m}^{3} / \mathrm{detik}$, luasan tergenang 122.568,098 $\mathrm{m}^{2}$. Debit maksimum kala ulang 10 tahunan maksimum adalah 196,693 $\mathrm{m}^{3} /$ detik, luasan tergenang 148.995,304 $\mathrm{m}^{2}$. Debit kala ulang 25 maksimum tahunan adalah 44,475 m3/detik, luasan tergenang 10.314,6 m². Debit kala ulang 50 maksimum tahunan adalah, 309,434 $\mathrm{m}^{3} /$ detik, luasan tergenang 255.356,377 $\mathrm{m}^{2}$. Debit banjir rencana maksimum akibat hujan 2-harian maksimum tahunan terjadi pada tahun 2009 yakni sebesar 281,846 $\mathrm{m}^{3} /$ detik, luasan tergenang $188.141,935 \mathrm{~m}^{2}$.
\end{abstract}

Kata kunci: Kelurahan Banyuanyar, Penelusuran Banjir, Metode Muskingum Cunge, Sistem Informasi Geografis.

\section{PENDAHULUAN}

Banjir merupakan bencana yang menjadi fenomena rutin di musim penghujan yang merebak di berbagai daerah aliran sungai (DAS) di sebagian besar wilayah Indonesia. Jumlah bencana banjir dalam musim hujan terus meningkat demikian juga dengan jumlah korban manusia maupun kerugian sarana dan prasarana umum. Banjir itu sendiri merupakan indikasi dari ketidak seimbangan sistem lingkungan dalam proses mengalirkan air permukaan dan dipengaruhi oleh besar debit air yang mengalir melebihi daya tampung daerah pengaliran (Suripin, 2004).

Tahun 2009 bencana banjir menerjang Surakarta, tidak terkecuali di daerah Kelurahan Banyuanyar, kecamatan Banjarsari Surakarta dengan kondisi yang cukup parah. Hal ini dikarenakan banjir yang terjadi di Kelurahan Banyuanyar memiliki ketinggian hampir mencapai $2 \mathrm{~m}$. Sebelumnya, Banyuanyar sendiri merupakan daerah yang tidak pernah terjadi banjir. Banjir yang menerjang Banyuanyar dikarenakan air dari Kali Pepe meluap ke pemukiman warga. Hal ini merupakan akibat dari Kali Pepe yang tidak dapat menampung kapasitas debit air hujan yang mengalir di kali tersebut. Apalagi belum diperbaikinya talut di tepi Kali Pepe yang membuat air limpasan kali meluap (Novi Dwi Astuti, 2013)

Debit banjir dengan periode ulang 5, 10, 25, dan 50 tahun akan dibandingkan dengan debit banjir maksimum tahunan. Berdasarkan debit banjir periode ulang tersebut, maka dapat dihitung muka air banjir dan site (posisi) banjir pada jam tertentu. Metode yang digunakan untuk menganalisis tinggi muka air banjir disebut penelusuran banjir. Penelitian ini penelusuran banjir menggunakan metode muskingum cunge. 
Hasil penelitian ini kemudian dipetakan dengan Sistem Informasi Geografis (SIG). Pemetaan dengan Sistem Informasi Geografis (SIG) menggunakan tiga parameter yaitu curah hujan, kelerengan dan Penggunaan lahan. Pemetaan daerah-daerah yang memiliki tingkat kerentanan banjir dapat dilakukan menggunakan perangkat GIS secara cepat mudah dan akurat terhadap parameter-parameter penyebab banjir, serta digunakan dalam pengolahan dan pembuatan peta curah hujan, peta penggunaan lahan, peta ketinggian (kontur), peta kelerengan, dan peta satuan lahan.

Penelitian ini akan membahas besarnya debit banjir tahunan yang mungkin terjadi di kelurahan Banyuanyar dari data hujan di setiap stasiun pencatat hujan terdekat. Hal ini dilakukan agar mengetahui potensi banjir di wilayah tersebut lebih pasti dan akurat. Data hujan selama 20 tahun yaitu dari 1997-2016, analisis banjir tahunan dapat dilakukan dengan data hujan harian, hujan 2 harian dan hujan bulanan maksimum tahunan. Perhitungan hujan 2 harian digunakan untuk menduga potensi bencana banjir kelurahan Banyuanyar, Surakarta.

\section{LANDASAN TEORI}

Analisis banjir ditinjau dari beberapa bagian, antara lain hidrolika, hidrologi, teknik sungai, morfologi dan sedimentasi sungai, sistem drainase kota dan bangunan air, serta erosi DAS. Selain itu, peristiwa banjir juga tidak lepas dari aspek-aspek lain yang menyangkut sosial, ekonomi, lingkungan, institusi pemerintahan, dan hukum.

Antisipasi yang dilakukan ketika banjir semakin sering terjadi adalah dengan cara menganalisisnya. Dampak yang lebih besar tersebut dapat dihindari dengan penelusuran sekaligus pemetaan potensi banjir pada daerah tersebut. Penelusuran banjir adalah suatu metode yang dilakukan unuk menentukan waktu dan debit aliran (hidrogaf) di suatu titik aliran berdasarkan hidrograf di suatu titik aliran berdasarkan hidrograf sebelah hulu (Bambang Triatmodjo, 2009).

Pemetaan daerah-daerah yang memiliki tingkat kerentanan banjir dapat dilakukan menggunakan perangkat GIS secara cepat mudah dan akurat terhadap parameter-parameter penyebab banjir, serta digunakan dalam pengolahan dan pembuatan peta curah hujan, peta penggunaan lahan, peta ketinggian (kontur), peta kelerengan, dan peta satuan lahan (Nurdin, 2015). Dalam pemetaan potensi banjir, terdapat cara untuk melakukan analisis banjir, salah satunya adalah ArcGIS dengan basis Sistem Informasi Geografis (SIG).

\section{Pengisian Data Hujan yang Hilang}

Pengisian data hujan yang hilang dilakukan dengan menggunakan metode Reciprocal dengan batasan stasiunstasiun hujan yang berlokasi dalam jarak kurang dari 30 kilometer. Data hujan yang hilang dapat dihitung dengan menggunakan Persamaan 1.

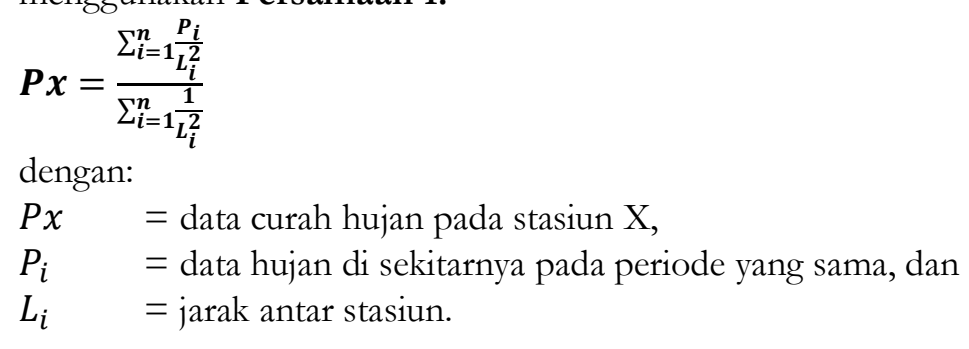

\section{Kepanggahan Data}

Data hujan yang dipakai dalam analisis dilakukan uji konsistensi dengan menggunakan metode kurva massa ganda (double mass curve). Kurva massa gamda digunakan sebagai pembanding suatu kumpulan data dengan kumpulan data lainnya yang secara garis besar memiliki kecenderungan yang sama atau memiliki nilai determinastik $\left(\mathrm{R}^{2}\right)$ yang mendekati 1. Jika ditemukan nilai $\mathrm{R}$ tidak mendekati 1, maka harus diperbaiki sehingga data dapat dikatakan konsisten. Adapun koefisien deterministik antara variabel $x$ dan $y$ dapat dicari dengan Persamaan 2.

$$
\begin{aligned}
& \boldsymbol{r}^{2}=\frac{\sum \boldsymbol{x}_{i} y_{i}-\sum \boldsymbol{x}_{i} \sum \boldsymbol{y}_{i} / n^{2}}{\sum \boldsymbol{x}_{i}^{2}-\left(\sum \boldsymbol{x}_{i}\right)^{2} / \boldsymbol{n}\left(\sum y_{i}\right)^{2}-\left(\sum y_{i}\right)^{2} / n} \\
& \text { dengan: } \\
& \begin{array}{ll}
i \quad=\text { data ke, dan } \\
n \quad=\text { jumlah data. }
\end{array}
\end{aligned}
$$




\section{Hujan Wilayah}

Metode yang digunakan dalam perhitungan curah hujan rata-rata wilayah daerah aliran sungai (DAS) ada tiga metode, yaitu metode rata-rata aritmatik (aljabar), metode poligon Thiessen dan metode Isobyet. Penelitian ini menggunakan metode poligon Thiessen, karena memperhitungkan bobot masing-masing stasiun yang mewakili kawasan di sekitarnya. Perhitungan hujan wilayah dengan metode Poligon Thiessen dapat menggunakan Persamaan 3 berikut.

$\bar{p}=\frac{A_{1} p_{1}+A_{2} p_{2}+\cdots+A_{n} p_{n}}{A_{1}+A_{2}+\cdots+A_{n}}$

dengan:

$\mathrm{p}=$ hujan rerata kawasan,

$\mathrm{p}_{1}, \mathrm{p}_{2}, \ldots \mathrm{p}_{\mathrm{n}} \quad=$ hujan di stasiun $1,2,3, \ldots . \mathrm{n}$, dan

$\mathrm{A}_{1}, \mathrm{~A}_{2}, \ldots \mathrm{A}_{\mathrm{n}} \quad=$ luas daerah yang mewakili stasiun $1,2, \ldots \mathrm{n}$.

\section{Distribusi Sebaran}

Setiap data hidrologi harus diuji kesesuaiannya dengan sifat statistik masing-masing sebaran. Pemilihan sebaran yang tidak benar dapat menciptakan kesalahan perkiraan yang cukup besar. Persamaan garis lurus bentuk kumulatif distribusi Log Pearson tipe III adalah (Soewarno, 1995) dapat dilihat pada Persamaan 4.

$$
\boldsymbol{Y}=\overline{\boldsymbol{Y}}-\boldsymbol{k} . \boldsymbol{S}
$$

dengan:

$\mathrm{Y} \quad=$ nilai logaritmik dari $\mathrm{X}$,

$\bar{Y} \quad=$ nilai rata-rata dari $\mathrm{Y}$,

$\mathrm{S} \quad=$ deviasi standar dari $\mathrm{Y}$, dan

$\mathrm{K} \quad=$ karakteristik dari distribusi Log Pearson Tipe III.

\section{Kecocokan Sebaran}

Analisis pada penelitian ini menggunakan uji kecocokan Smirnov-Kolmogorov. Pengujian dilakukan dengan cara membandingkan probabilitas pada tiap-tiap variabel dari suatu distribusi yang hasilnya akan didapat perbedaan $(\Delta)$. Perbedaan maksimum ( $\Delta$ maks) yang dihitung dibandingkan dengan perbedaan kritis $(\Delta \mathrm{cr})$ untuk banyaknya varian tertentu. Sebaran dikatakan sesuai jika $\Delta$ maks $<\Delta$ cr (Soewarno, 1995)

\section{Hujan Efektif}

Hujan efektif adalah bagian dari hujan total yang menghasilkan limpasan langsung. Hujan efektif merupakan hasil perkalian dari koefisien limpasan dengan hujan total, terdapat dalam Persamaan 5 berikut ini.

$P_{e}=\frac{(P-0,2 S)^{2}}{P+0,8 S}$

dengan:

$P_{e} \quad=$ kedalaman hujan efektif $(\mathrm{mm})$,

$P \quad=$ kedalaman hujan $(\mathrm{mm})$, dan

$S \quad=$ retensi potensial maksimum air oleh tanah, yang sebagian besar karena infiltrasi (mm).

Retensi potensial maksimum dapat dihitung dengan Persamaan 6 berikut ini (SCS, 1972).

$S=\frac{25400-254 C N}{C N}$

dengan:

$S=$ retensi potensial maksimum air oleh tanah, yang sebagian besar karena infiltrasi ( $\mathrm{mm})$, dan

$C N=$ Curve Number.

\section{Waktu Konsentrasi}

Waktu konsentrasi adalah waktu yang diperlukan untuk bergeraknya air dari titik aliran terjauh dari suatu DAS sampai dengan titik pelepasan. Waktu konsentrasi dapat dihitung dengan beberapa rumus seperti rumus Kirpich yang ditampilkan pada Persamaan 7 (Tata Cara Perbitungan Debit Banjir Rencana, SNI 2415:2016).

$t_{c}=\mathrm{f} \cdot L^{0,77} \cdot S^{-0,385}$

dengan:

$t_{c} \quad=$ waktu konsentrasi (jam),

$L \quad=$ panjang saluran utama lintasan air $(\mathrm{km})$,

$S \quad=$ kemiringan rata-rata saluran $(\Delta \mathrm{H} / \mathrm{L})$, dan 


\section{Intensitas Hujan}

Intensitas curah hujan adalah ketinggian curah hujan yang terjadi pada suatu kurun waktu di mana air tersebut berkonsentrasi. Analisis intensitas curah hujan ini dapat diproses dari data curah hujan yang telah terjadi pada masa lampau. Metode perhitungan intensitas hujan antara lain adalah Mononobe, Sherman, Talbot dan Ishigoro. Penelitian ini menggunakan metode Mononobe yang disajikan pada Persamaan 8 (Rosadana Nurir, 2015).

$I_{t}=\frac{R_{24}}{t_{c}}\left[\frac{t_{c}}{t}\right]^{2 / 3}$

dengan:

$I_{t} \quad=$ Intensitas curah hujan pada jam ke- $t(\mathrm{~mm} / \mathrm{jam})$,

$\mathrm{R}_{24}=$ tinggi hujan rancangan dalam 24 jam $(\mathrm{mm})$,

$t_{c} \quad=$ waktu konsentrasi (jam), dan

$t \quad=$ jam ke-1 s.d. jam ke- $t$.

\section{Hidrograf Satuan Sintetis Soil Conservation Service (HSS SCS)}

HSS SCS (Soil Consevation Service) adalah hidrograf satuan sintetis yang dikembangkan oleh Victor Mockus pada tahun 1950 dengan lokasi penelitian di Amerika Serikat. Hidrograf ini menggunakan fungsi hidrograf tanpa dimensi untuk menyediakan bentuk standar hidrograf satuan. Persamaan yang digunakan dalam perhitungan HSS SCS mengikuti Persamaan 9 sampai dengan Persamaan 17 (BSNI, 2016).

$Q p=q p \cdot P e \cdot 0,028$

$q p=\frac{A}{T_{0} \text { terkoreksi }} \cdot 484$

To tker $=\frac{\text { Time ratio. } T_{c}}{1,5}$

$\frac{T_{0}}{T_{p}}=\frac{T_{r} \cdot T_{c}}{T_{p}}$

$T_{c}=0,01947 \cdot L^{0,77} \cdot S^{-0,385}$

$T p=\frac{0,24 \cdot t_{c}}{2}+t_{p}$

tp $=0.51 \cdot L 0,8$

$P e=\frac{(P-0,2 S)^{2}}{P+0,8 S}$

$S=\frac{25400}{C N}-254$

dengan:

$Q_{p}=$ debit puncak limpasan $\left(\mathrm{m}^{3} / \mathrm{s}\right)$,

$q_{p}=$ debit puncak (in),

$T_{c}=$ waktu konsentrasi (jam),

$T_{p}=$ waktu puncak $\left(\mathrm{m}^{3} / \mathrm{s}\right)$,

$t_{p}=$ waktu antara titik berat curah hujan hingga puncak hidrograf (jam),

$t_{r}=$ time ratio,

$A=$ luas DAS (in),

$L=$ panjang sungai utama $(\mathrm{km})$,

$S=$ kemiringan sungai,

$P_{e}=$ kedalaman hujan efektif (in),

$P=$ kedalaman hujan maksimum (in), dan

$S=$ infiltrasi maksimum yang terjadi (in),

$C N=$ curve number.

\section{Penelusuran Banjir}

Cunge, 1969, mengembangkan Metode Muskingum untuk penggal sungai tanpa aliran lateral, tetapi mendapatkan nilai parameter penelusuran (Ci) secara langsung. Metode ini membutuhkan data hidrograf inflow dan data fisik penggal sungai yang ditinjau. Pada dasarnya metode Muskingum menggunakan parameter $\mathrm{K}$, X, dan $\mathrm{Ci}$ dalam penelusuran banjir suatu penggal sungai (Sobriyah dan Sudjarwadi, 2000), yang ditunjukkan pada Persamaan 18 sampai 24 berikut.

$O_{j+1}=C_{1} I_{j}+C_{2} I_{j+1}+C_{3} O_{j}$ 


$$
\begin{aligned}
& Q=A\left(\frac{1}{n} R^{2 / 3} S^{1 / 2}\right) \\
& D=\frac{\left(\frac{Q}{L a}\right)}{(S \times v \times \Delta x)} \\
& C r=v \times \frac{\Delta t}{\Delta x} \\
& C_{1}=\frac{-1+C r+D}{1+C r+D} \\
& C_{2}=\frac{1+C r-D}{1+C r+D} \\
& C_{3}=\frac{1-C r+D}{1+C r+D}
\end{aligned}
$$

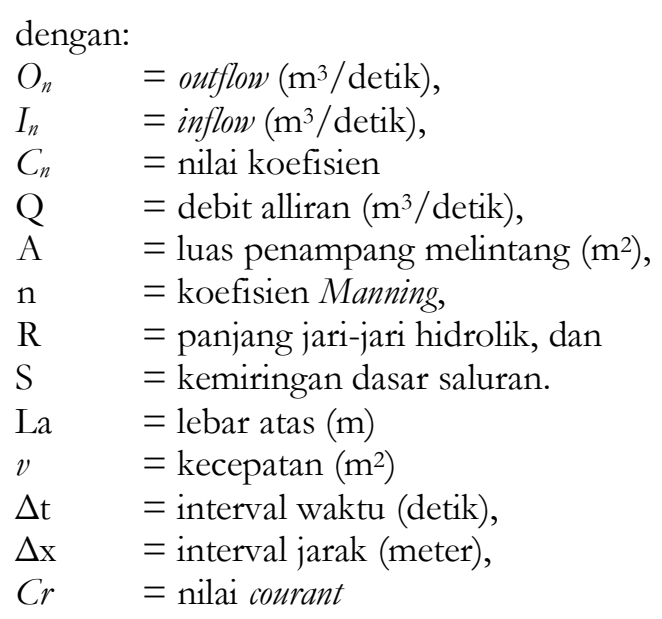

\section{Pemodelan Aliran Tidak Tetap dengan HEC-RAS}

Penelusuran banjir adalah salah satu contoh pemodelan hidrolik dengan prinsip unsteady flow. Untuk aliran tak permanen, HEC-RAS memakai persamaan kekekalan massa (continuity, conservation of mass) dan persamaan momentum. Kedua persamaan dituliskan dalam bentuk persamaan diferensial parsial, yang kemudian diselesaikan dengan metode finite difference approximation berskema implisit (Istiarto, 2014). Pemodelan menggunakan HECRAS akan menghasilkan tinggi permukaan air yang dihasilkan dengan memperhitungkan geometri sungai dan beberapa batasan bagian sungai.

\section{Pembuatan Peta Potensi Wilayah Tergenang dengan Sistem Informasi Geografis}

Sistem informasi geografis adalah teknologi informasi yang dapat menganalisis, menyimpan, dan menampilkan data spasial dan non-spasial. SIG mengkombinasikan perangkat lunak berbasis data relasional dan paket perangkat lunak CAD (Guo Bo et. all 2000 dalam Prahasta, 2009). Pemetaan potensi wilayah tergenang dengan memanfaatkan program ArcMap dan pemodelan dengan menggunakan HEC-RAS.

Pada tahapan pertama, dengan data masukan berupa DEM dan garis sungai yang diteliti, akan dihasilkan property fisik sungai seperti garis tengah aliran sungai (stream centerlines), arah aliran sungai (flow path centerline), tepian sungai (banks), hingga pototngan melintang (cross-section). Kedua, setelah proses selesai, kemudian pemodelan menggunakan HEC-RAS. Pada bagian river geometry, dimasukkan data berupa olahan dari proses sebelumnya. Kemudian, aliran dimodelkan unsteady flow. Seluruh data yang dihasilkan dari analisis ini kemudian diekspor ke dalam format GIS. Proses terakhir input hasil ke HEC-GeoRAS, hasil pengolahan pada pogram HEC-RAS. Dipilih menu Inudation Mapping untuk memetakan genangan.

\section{METODE PENELITIAN}

Metode penelitian yang digunakan adalah deskriptif kuantitatif. Analisis penelusuran banjir menggunakan metode Muskingum Cunge dengan bantuan hidrograf satuan sintetik Soil Conservation Service (HSS SCS) di Kali Pepe Hulu. 
Penelitian dilakukan di Kelurahan Banyuanyar, Kecamatan Banjarsari, Kota Surakarta, dengan memanfaatkan beberapa data sekunder yang meliputi:

1. Peta digital dengan skala 1:25 000 Kota Surakarta produksi Badan Informasi Geospasial (dahulu Bakosurtanal), termasuk di dalamnya peta administrasi, peta sungai, dan peta kontur.

2. Peta Digital Elevation Method (DEM) produksi United States Geological Survey (USGS)

3. Data curah hujan dari 3 (tiga) stasiun terdekat dari wilayah tinjauan; yakni Stasiun Pabelan, Stasiun Ngemplak, dan Stasiun Nepen di bawah Balai Besar Wilayah Sungai (BBWS) Bengawan Solo serta Balai Pekerjaan Umum Sumber Daya Air dan Penataan Ruang (BPUSDATARU) Bengawan Solo dari tahun 1998 sampai 2017.

4. Data potongan melintang sungai (cross section) yang didapatkan dari BBWS Bengawan Solo.

Data di atas kemudian diolah dengan menggunakan bebrapa perangkat digital yang terdiri dari:

1. Microsoft Excel untuk perhitungan analisis data hujan dan debit banjir.

2. ArcMap versi 10.3.1 untuk mengolah peta digital serta properti terkait pemetaan banjir di Kelurahan Banyuanyar, Kecamatan Banjarsari, Surakarta.

3. HEC-RAS versi 5.0.1 untuk pemodelan hidrolika sungai.

\section{HASIL DAN PEMBAHASAN}

Penelusuran Banjir dengan Metode Muskingum Cunge

Tabel 1 menampilkan rekapitulasi hasil penelusuran banjir untuk masing-masing debit maksimum dan luas wilayah akibat hujan kala ulang dan akibat hujan 2-harian.

Tabel 1 Rekapitulasi Penelusuran Banjir pada Keadaan Debit Maksimum dan Luas Wilayah Tergenang

\begin{tabular}{cccccc}
\hline & $\mathrm{Q}_{5}$ & $\mathrm{Q}_{10}$ & $\mathrm{Q}_{25}$ & $\mathrm{Q}_{50}$ & $\mathrm{Q}_{2-\text { Harian }}$ \\
\hline Debit Maksimum $\left.\mathbf{( m}^{\mathbf{3}} / \mathbf{s}\right)$ & 143,748 & 196,693 & 309,434 & 483,759 & 281,846 \\
\hline Luas Wilayah $\left(\mathbf{m}^{2}\right)$ & $122.568,098$ & $148.995,304$ & $206.264,739$ & $255.356,377$ & $188.141,935$ \\
\hline
\end{tabular}

\section{Pemetaan Wilayah Potensi Tergenang}

Pemetaan wilayah yang berpotensi tergenang dilakukan dengan menggunakan program ArcMap 10.3.1, yang hasilnya dapat dilihat pada Gambar 1 hingga Gambar 5.

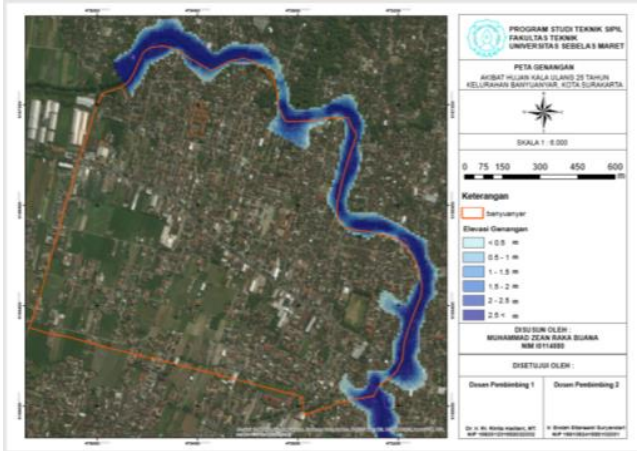

Gambar 1 Peta Potensi Genangan akibat Hujan Kala Ulang 5 Tahun

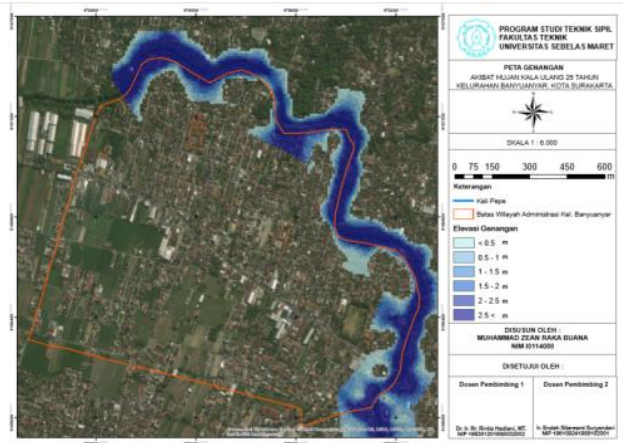

Gambar 3 Peta Potensi Genangan akibat Hujan

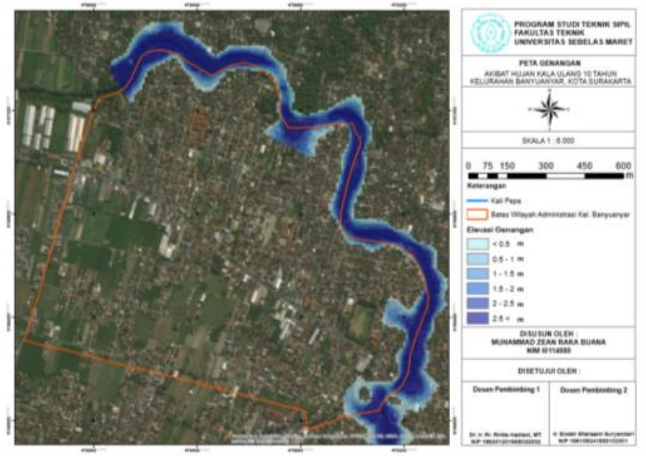

Gambar 2 Peta Potensi Genangan akibat Hujan Kala Ulang 10 Tahun

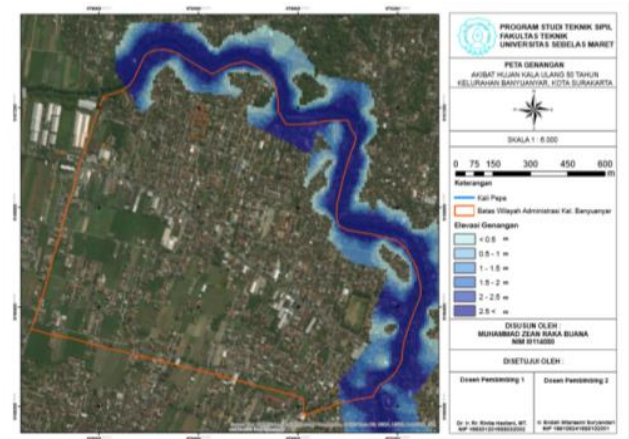

Gambar 4 Peta Potensi Genangan akibat Hujan 


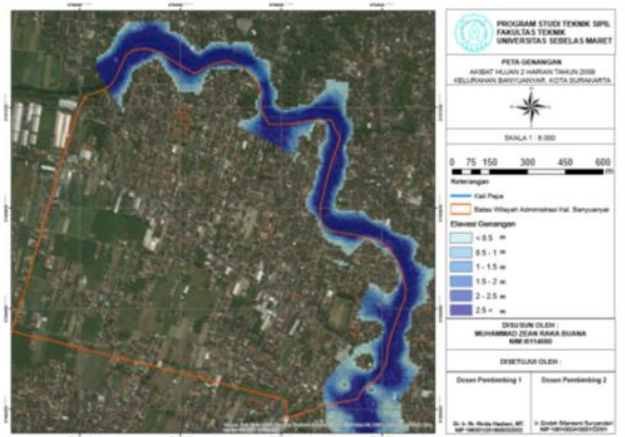

Gambar 5 Peta Potensi Genangan akibat Hujan 2-Harian Maksimum Tahunan (2009)

\section{Potongan Melintang Potensi Genangan}

Potongan melintang di beberapa titik akibat hujan 2-harian maksimum tahunan yang terjadi pada tahun 2009 didapatkan dengan menggunakan program HEC-RAS 5.0.1, yang hasilnya dapat dilihat pada Gambar 6 hingga Gambar 10.

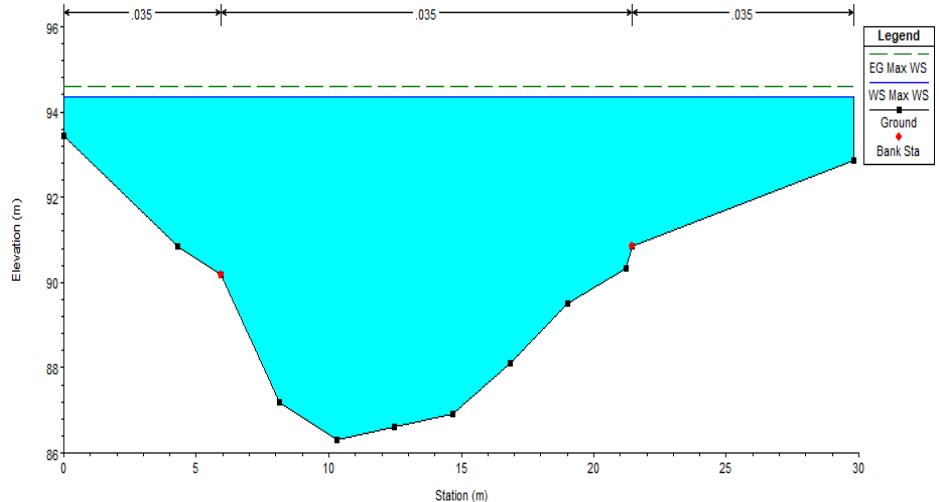

Gambar 6 Potongan Melintang pada Titik 12

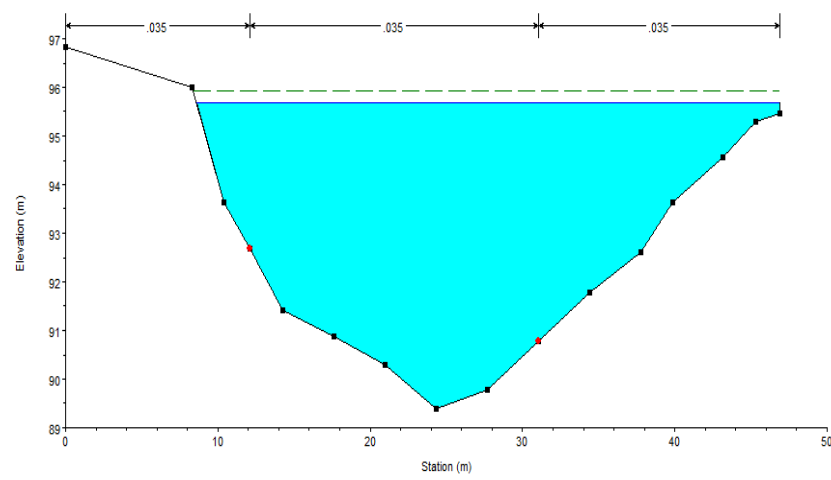

Gambar 8 Potongan Melintang pada Titik 26

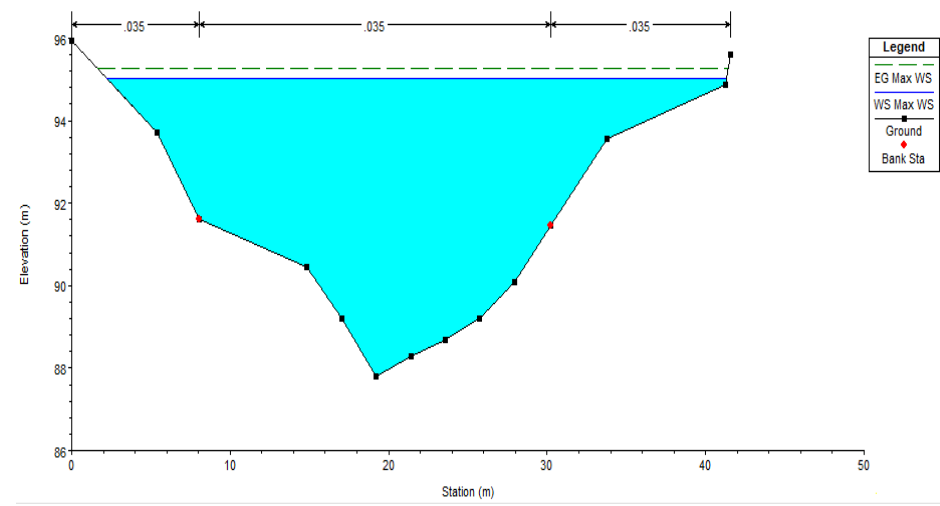

Gambar 7 Potongan Melintang pada Titik19

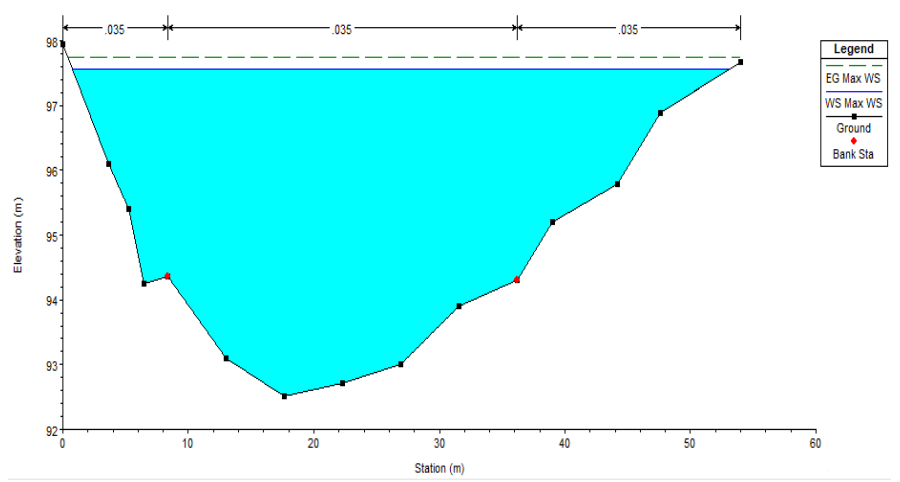

Gambar 9 Potongan Melintang pada Titik 33 


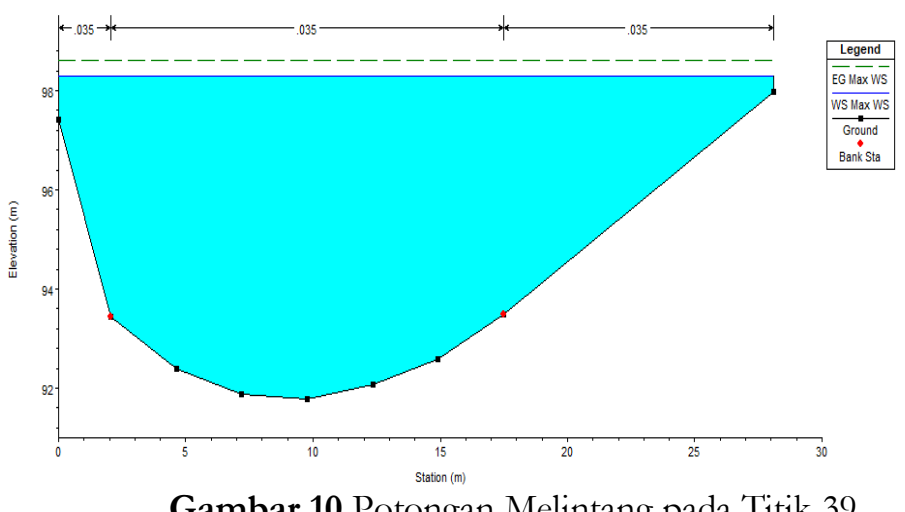

Gambar 10 Potongan Melintang pada Titik 39

\section{SIMPULAN}

Debit banjir rencana periode ulang 5 Tahun $\left(\mathrm{Q}_{5}\right)$ adalah 144,748 m3/detik, periode ulang 10 Tahun $\left(\mathrm{Q}_{10}\right)$ adalah 196,693 m3/detik, periode ulang 25 Tahun $\left(\mathrm{Q}_{25}\right)$ adalah 309,434 m3/detik, dan periode ulang 50 Tahun $\left(\mathrm{Q}_{50}\right)$ adalah, 483,749 m3/detik. 2. Debit banjir rencana maksimum akibat hujan 2-harian maksimum tahunan terjadi pada tahun 2009 yakni sebesar 218,846 m3/detik.

\section{REKOMENDASI}

1. Kelengkapan data yang diperlukan dalam penelitian sehingga data mudah diakses maupun didapatkan.

2. Perlu adanya kajian terhadap pengaruh drainase kota sehingga dapat memaksimalkan hasil dalam mendapatkan daerah mana saja yang tergenang.

\section{UCAPAN TERIMA KASIH}

Ucapan terima kasih pertama ditujukan kepada Allah SWT atas limpahan rahmat dan nikmatnya. Selanjutnya kepada Dr. Ir. Rr. Rintis Hadiani, M.T. dan Ir. Endah Sitaresmi Suryandari selaku dosen pembimbing yang telah memberi arahan dan masukan dalam penelitian ini.

\section{REFERENSI}

Andromeda, Virdya Nurlaily. 2013. Penelusuran Banjir di Sungai Temon Sub DAS Bengawan Solo Hulu III dengan Metode Muskingum-Cunge. Universitas Sebelas Maret. Surakarta

Chow, V.T., Maidment, D.R., and Mays, L.W. 1988. Applied Hydrology. McGraw-Hill. Singapore.

Dewandaru, Gemma Galgani Tunjung dan Umboro Lasmito. 2014. Studi Penanggulangan Banjir Kali Lamong Terhadap Genangan di Kabupaten Gresik. Jurnal Teknik POMITS. Volume 3, No. 2, (2014) ISSN:23373539

Flood Hydrology Manual. United States Bureau of Reclamation. 1989.

Florince, dkk. 2015. Studi Kolam Retensi sebagai Upaya Pengendalian Banjir Sungai Way Simpur Kelurahan Palapa Kecamatan Tanjung Karang Pusat

Montarcih, Lily. 2010. Penelusuran Banjir lewat Sungai : Studi kasus Sungai Dodokan. CV Citra Malang. Malang.

Naulita, Maria Anisa. dkk. 2015. Metode Penelusuran Banjir pada Sungai Dengkeng dengan Metode Gabungan O’Donnel dan Muskingum-Cunge dan Metode Muskingum Extended. Fakultas Teknik. Universitas Sebelas Maret. Surakarta.

Ponce, Victor Miguel. 1989. Engineering Hydrology : Principles and Practices. Prentice Hall Inc. New Jersey, United States of America.

Sobriyah. 2012. Model Hidrologi. Sebelas Maret University Press. Surakarta.

Sobriyah dan Sudjarwadi. 2000. Penggabungan Metode O'Donnel dan Muskingum - Cunge Untuk Penelusuran Banjir Pada Jaringan Sungai. Media Teknik no. 4 Tahun XXII edisi November.

Soemarto, C. D., 1986. Hidrologi Teknik. Erlangga. Jakarta.

Soewarno. 1995. Hidrologi: Aplikasi Metode Statistik untuk Analisa Data Jilid 1. Penerbit Nova. Bandung.

Sosrodarsono, S., Takeda, K, 1993. Hidrologi Untuk Pengairan. PT Pradnya Paramita. Jakarta

Standar Nasional Indonesia. 2016. Tata Cara Perhitungan Debit Rencana. 2415:2016.

Suripin. 2004. Sistem Drainase Perkotaan yang Berkelanjutan. Andi Offset. Yogyakarta.

Triatmojo, Bambang. Hidrologi Terapan. 2008. Beta Offset. Yogyakarta 